\title{
How to Deal with Underprivileged Classroom
}

\author{
Afaf Abdelrahim Jalaleldin Ahmed \\ Lecturer at Almughtaribeen University Sudan \\ Lecturer at Aldamamm University Saudi Arabia \\ Lecturer at Hafralbatin University Saudi Arabia
}

\begin{abstract}
Underprivileged or large classrooms are a phenomenon inflicting poverty stricken zones of the world. Due to the harsh economic realities these countries could not afford to provide the hygiene and proper environments for learning. Whether, at the basic or secondary levels classrooms are fully packed with students beyond the capacity of the room. Teachers find it difficult to impart knowledge in such inhospitable atmosphere. Certain parts of the syllabus will go untaught as long as large classes reality does not favor the handling of such learning and teaching materials. The researcher seeks to provide an insight in this article as to how to teach underprivileged or large classroom through a proper teaching approach. Collaborative learning can be cited at this juncture as an example for handling such classes.
\end{abstract}

Keywords: underprivileged, phenomenon, harsh economic realities, hygiene, impart knowledge, untaught, handling

\section{INTRODUCTION}

With the spread of learning and schooling, the phenomenon of large classes has started to appear as a natural concomitant to that ongoing development or increase of students' numbers. A large class may include over one hundred students. In some environment a large class may signify a class of 50-70 students. Large classes are most common in the first year of study at university. This may further double the efforts the tutors exert to teach handle these classes. The impact of these classrooms on students may vary that some might find it difficult to keep up with the tutors while delivering their lectures, and that some may abandon the university altogether at extreme instances. Consequently, teaching large classes requires a wide-range of skills and strategies:

- Effective classroom management to present effectual lectures

- Providing good opportunities for the students to take part in the process of lecturing

- Incorporating effective innovative learning elements to create genuine interest in learning and hence facilitate the operation of learning

- Exploiting as far as possible technology facilities while not ignoring face-to face teaching

- Adopting a kind of collaborative learning not mention enlisting the help of other colleagues.

Large classes are often perceived as one of the major obstacles to ensuring quality education. Indeed, there are many research studies that point to the disadvantages of large classes and advocate small classes as a factor to ensure quality education. In spite of this, large classes are a reality in many schools and many countries, often as a direct result of inadequate funding and the absence of political will to provide a sufficient number of teachers and classrooms that would ensure a quality education. Providing tools to address the difficulty of teaching large classes is thus an important step towards realizing quality education for all (EFA) in school settings.

This guide does not offer a universal solution to all the challenges related to teaching in large classes. It attempts to present a variety of practical methods and practices that could be useful for teachers who need to deal with a large class every day. It addresses issues such as how to prepare and plan lessons specifically adapted for large classes. Furthermore, it provides useful tips and pointers to manage the class in the best possible way and to see the large class as a resource, rather than a challenge, to the teaching-learning process. It is also about changing the perspective from teaching that focuses solely on didactic approaches to more child-centered and learning-friendly methods. 
An inclusive, learning- friendly environment (ILFE) is about being friendly not only to children, but also to teachers. Teachers are the single most important factor in improving and ensuring the quality of education. Responsibility for preparing students for the future largely falls to them.

\section{Psychological EfFect on Tutors}

Tutors handling large classes are always under great pain and pressure being completely helpless and incapable of presenting their classes. For many teachers faced with large classes, we might be tempted to give up, thinking that there is no chance of getting so many students to learn. The problem is, however, that we assume that learning occurs in proportion to class size. The smaller the class, the more students learn. However, research shows that class size does not automatically correlate with student learning. Students in large classes can learn just as well as those in small ones. What counts is not the size of the class, but the quality of the teaching. Evidence shows that students place more emphasis on the quality of teaching than class size. Moreover, they may not mind being in a large class as much as you may think they do, or as much as you mind it yourself.

Doin .L (1996) in an article entitled "But, I teach Large Classes", admits that...

I have taught hundreds of students over the span of many years, and my current class has 80 students. At first, I realized that I had finally achieved that comfortable security of having a ready-made set of lecture notes, volumes of exam and quiz questions, and a sense of predictability regarding the course. Strangely enough, however, I was also bored and bothered. Bored from lecturing about the same things year after year, and bothered because my lectures came across so rigidly that I was failing to impart to my students the satisfaction of finding solutions to problems.

Teaching large classes is a challenge, but it can also offer many opportunities for you to improve your teaching and to make it more enjoyable and rewarding for you and your students.

In a large class setting, you have the opportunity to improve your organizational and managerial skills as you work to creatively organize your classroom into a comfortable, welcoming learning environment and to manage the many students within it.

Large classes offer you the opportunity to improve your interpersonal skills as you try different ways to get to know each student as an individual through their work in class or their lives outside of it. They will also equally enjoy getting to know you.

Large classes give you the opportunity to improve your teaching and presentation skills. As the teacher above mentions, constantly lecturing to a large class - or even a small one - can become boring and bothersome. The value of a large class is that it contains a diversity of students and learning styles and you can use many different, active, and fun ways of teaching. The cumulative knowledge, experiences, skills, and interests of your many students, furthermore, can be valuable starting points for planning lessons and activities so that learning becomes meaningful for your students. In addition, by involving your students' families, you will also have greater access to resources for learning for learning.

You will also improve your evaluation skills as you devise a variety of ways to tell whether your students have really learned the material, instead of relying only on short answer exams, which may seem necessary for large classes. For instance, you can give your students in- class and out- of- class assignments that ask them what they have learned and what questions they have about what they have learned. Rather than following your students' failures, you can also track their successes, which are also your successes in teaching. You will find also that involving your students in their learning and in assessing how well they have done can save you time and reduce your workload.

\section{What is a Large Class?}

There is no exact definition for the term a large class. Nolasco \& Arther (1988) say that:

"Teachers who are used to group of (12-14) students, might find a group of (20) be rather threatening. Others may be relieved where they have only 40 " P.4.

If we compare the numbers mentioned in this statement with the numbers in our schools, we will find that there is no less than (50) students in our classes. And as a result, we will notice that some students will be seated much far away from the teacher who always stands or moves near the front centre of the class by the board. K.U. Qian (1992) States: 
In large classes, the classroom is necessarily very big so it is not easy to communicate with individual students. The students have comparatively few chances to speech and to answer questions On the other hand, the teacher has few chances to answer Questions and instructs each individually-

This statement means that, the teacher is responsible for every student and he must observe all the students whether in the front of the class or at the back seats. This observation, moreover, refers to the individual differences between the students. The teacher must know that although they are grouped in one class according to their ages, they differ in their mental maturity, physical abilities and in other respects such as, for example, their aptitude for learning and acquiring language.

These differences, of course, are particularly acute in large class, and teacher will find wide range of individual differences between students. So, only qualified teacher can be aware of these differences which can be in difficulties in seeing or hearing or other handicaps.

On the other hand, teacher has to take care of good lighting, ventilation and the rows of chairs and desks inside the class. He has to arrange these chairs and desks in a suitable way so as to be able to move in an easy way to check and construct his students. Other problem is that the "following up" in the $5^{\text {th }}, 6^{\text {th }}, 7^{\text {th }}$ classes which are the first stages in learning English in our Basic Level Schools in general, and the $8^{\text {th }}$ class in particular, is very important because these students are always in need of a great deal of practice. They are also in need of individual following up in handwriting, pronunciation and writing words correctly and accurately. So the class of (70) and above is not an ideal class for learning English, and we never expect a great improvement or good results in such classes. Another thing is that as a result of the heavy burden on the teacher, and his unintentional negligence to some students, they hate and neglect this subject.

\section{Classroom Environment}

Large classes, usually, cause unsuitable conditions for teaching and learning language. Thus, the teacher is the first one who must be responsible for creating a suitable and good environment as to enable all the students inside the class to participate and interact with what is presented to them. So teachers in large classes must:

a) Notice that the light in the classroom is good and enough for everyone whether in front of or at the back of the class.

b) Make sure that the spaces between desks and chairs are at least $(50-60)$ centimeters as to enable the teacher to move easily inside the class to follow up and check the students work.

c) Know that learning students' names, always creates friendly atosphere, and makes them feel that they are important persons. Nolasco, (1988- P.10) says "It's always very important to find out about your students, and the first step in this process, is learning their names. He also says "knowing the students names, allows you to nominate students with confidence, as well as to identify trouble makers".

d) Keep the class in a good order and discipline, because it's one of the most important factors in the learning process. Jacobson et al, (1981, P.205) say: "... The concept of management is often hard to differentiate from the concept of instruction, and the two are closely related in theory and practice. The good classroom manager is often a good instructor. ". So every teacher must consider the ways of keeping his class in a good order before the beginning of the lesson. Nolasco, (1988- P.21) believes that Maxims like "Be firm but fair", "Have a few reasonable rules and stick to them", ".....they are of little practical help to those problems and techniques for establishing and maintaining order.". Other problem of discipline is the problem of keeping his class quiet as to enable every one hear clearly, share in asking and answering questions and participate in the class.

e) Take care of marking exercise books, because if he neglects this work, students will neglect doing their homework. To make this job easier, Hill and Dobbyn, (1981, P.30) say: "..., self-correcting exercises is very important in large classes, as it enables the teacher to give pupils plenty of reading and writing work, which they need, while using immediate reinforcement and not overburdening himself with correcting work".

\section{Group/PAIR WORK}

Teacher has to avoid, as can as possible, the lecturing and dominating the time of the period, and instead, he can divided the students into groups or pairs as to give them the chance to participate and share in the different activities inside the class. Dividing students into groups must be according to 
their levels, that is to say, he must be aware of good and weak ones as to enable them to help each other. Byrne, (1987, P.77) States: "You should normally form the groups yourself, usually in the basis of mixed ability (e.g. good and weak students together) since as a rule learners do help one another."

Hill and Dobbyn also state that "Group work in which pupils work together in groups makes things easier." P29.

Although more than one agree that group work makes things easier, in contrast Taska, $(1989, \mathrm{P}, 13)$ believes that "if he divides the students into groups and gives them activity to be done, he cannot give every group enough care to correct its mistakes or to know whether the students in a given group are really doing their duty"..

This leads us to discuss the advantages and the disadvantages of pair and group work and to compare between them.

\subsection{The Advantages of Pair/Group Work}

a) It allows the students to use and practice the language as a whole class, and makes them less shy about making mistakes.

b) It gives the students the chance to speak English when they work in pairs or groups, because each student makes several sentences, questions or answers.

c) If the same exercise is done around the class, some students may say only one sentence, and many will say nothing at all.

d) Some students, when they are (on show) in front of the class, become shy and never say anything, but they do well in group or pair work.

e) Students help each other, and share ideas. It also gives the chance for passing information to each other, because one of them may know something that others don't know.

\subsection{The Disadvantage of Pair/Group Work}

There are many disadvantages in pair and group work which can be included in the following:

a) Organization is difficult for group and pair work in large classes.

b) Lazy ones don't share in this of work.

c) There may be a problem of indiscipline from time to time.

d) Some students don't ask teacher when they face any difficulty.

e) Teacher, most of his time, acts as an instructor to keep quiet, instead of a facilitator and a consultant.

f) There is no chance to correct the students' faults.

g) Some of the students don't know how to do the activity which they have to do, or asked to do.

h) To sum up, if we compare the advantages and the disadvantages of this technique we will find that the advantages are greater than the disadvantage.

\section{MATERIAL AND MethodS}

This part describes the method of collecting data for this study. Data was collected from the teachers of boys and girls schools at Omdurman Locality. This Locality is characterized by large classes.

Questionnaire was used because it enables the researcher to collect large amount of information in a short time. Many steps and ways were done to collect data.

\subsection{Instrument}

The instrument used is a questionnaire consists of (20) items asking the teacher different questions about the years they have been teaching English, the number of students in their classes, the differences between teaching large and small classes, the teaching techniques they use in their classes, the problems of controlling, following up and marking exercise books, the relationship between the teachers and their students....etc.

\subsection{Population of the Study}

The population of the study is the teachers in Omdurman- Omdurman State. The schools were randomly selected from a large number of the schools which are characterized by the large classes. The questionnaire was distributed among a sample consists of 20 teachers. All the teachers were very interested in answering the questionnaire and giving their opinions 


\subsection{Method of Analysis}

Percentage and average are used to describe data. The observations of the researcher in these schools were:

- In some schools there are very experienced teachers while in others there are untrained ones.

- Female teachers who work in boy's schools - as a result of the shortage of male teachers, face many problems in large classes. Asking them about their experience in boy's schools, most of them said that they suffer a lot of the boys and their troubles, especially the boys in the $8^{\text {th }}$ class.

\section{ANALYSIS \& DiscuSSION}

The statistical analysis of the questionnaire which was distributed at Omdurman Locality in Khartoum reflects the following results. See the following table:

Table1. Percentage of Score of the Teachers' Questionnaire

\begin{tabular}{|c|c|c|c|}
\hline Questions & \multicolumn{3}{|c|}{ Percentage } \\
\hline 1- Teaching experience & $\begin{array}{l}0-10 \\
60 \%\end{array}$ & $\begin{array}{l}11-20 \\
30 \%\end{array}$ & $\begin{array}{l}\text { more than } 20 \\
10 \%\end{array}$ \\
\hline 2- Crowded classes. & $45 \%$ & & \\
\hline 3- Teaching small classes. & $70 \%$ & $30 \%$ & \\
\hline 4- Negative effect of large classes. & $100 \%$ & & \\
\hline 5- Presentation. & $60 \%$ & $\begin{array}{l}\text { pairwork } \\
40 \%\end{array}$ & \\
\hline 6- Giving homework. & $90 \%$ & $10 \%$ & \\
\hline 7- Giving homework. & $\begin{array}{l}\text { weekly } \\
40 \%\end{array}$ & $\begin{array}{l}\text { daily } \\
30 \%\end{array}$ & $\begin{array}{l}\text { monthly } \\
10 \%\end{array}$ \\
\hline 8- Homework assignment. & $\begin{array}{l}30-50 \% \\
40 \%\end{array}$ & $\begin{array}{l}10-20 \\
30 \%\end{array}$ & $\begin{array}{l}\text { other times } \\
20 \%\end{array}$ \\
\hline 9- Students participation. & $10-30 \%$ & & \\
\hline 10- Participation of back seat students. & $10-30 \%$ & & \\
\hline 11- Knowing students name. & $80 \%$ & & \\
\hline 12- Range of knowing the names. & $20 \%$ & & \\
\hline 13- Formal relationship. & $10-30 \%$ & & \\
\hline 14- teacher-student interaction. & $\begin{array}{l}\text { formal } \\
50 \%\end{array}$ & $\begin{array}{l}\text { friendly } \\
30 \%\end{array}$ & $\begin{array}{l}\text { impersonal } \\
20 \%\end{array}$ \\
\hline 15- Using direct questions. & $50 \%$ & & \\
\hline 16- Chairs inside the class. & $100 \%$ & & \\
\hline 17- Movement inside the class. & $\begin{array}{l}\text { uneasy } \\
80 \%\end{array}$ & $\begin{array}{l}\text { easy } \\
20 \% \\
\end{array}$ & \\
\hline 18- Standing in front of the class. & $\begin{array}{l}\text { in front } \\
70 \%\end{array}$ & $\begin{array}{l}\text { move around } \\
20 \%\end{array}$ & $\begin{array}{l}\text { in the middle } \\
10 \%\end{array}$ \\
\hline 19- Class management. & $\begin{array}{l}\text { able } \\
80 \%\end{array}$ & $\begin{array}{l}\text { unable } \\
20 \%\end{array}$ & \\
\hline 20- Talking aloud. & $\begin{array}{l}\text { aloud } \\
54.2 \%\end{array}$ & $\begin{array}{l}\text { shouting } \\
45.8 \%\end{array}$ & \\
\hline
\end{tabular}

a) The answers of question one show that $60 \%$ of the respondents have been teaching English in the range between $(0-10)$ years, $30 \%$ of them in the range between $(11-20)$ years and $10 \%$ of them more than 20 years. This table indicates that those teachers are experienced teachers, and the information given can be taken in consideration.

b) The answers of question two show that the highest percentage (45\%) of the number of students in each class, range between (70-90) student. This result shows that there are "large classes" which is the origin of the problem which this research tries to investigate. This result also contrasted with Rob Nolasco (1988, P.4) when he stated: "Teachers may be relieved when they have only 40 students in the classrooms."

c) The answers of question three show that the majority the teachers $(70 \%)$ had the experience of teaching small class, and only (30\%) had no experience in teaching less than 50 students. According to this result we can say that the majority of the respondents can recognize the differences between teaching large and small classes.

d) The answers of question four show the differences between teaching large and small classes. All the teachers agreed that large classes affect both students and teachers negatively. This agrees 
with the hypothesis of this study which states that large class affect the performance of both teacher and student negatively.

e) The answers of question five show that $60 \%$ of the respondents use presentation and lecturing techniques, while $40 \%$ use pair/group work. In discussing this result, it's noticed that although it's more effective to use the technique of dividing students into pairs and groups, but as a result of the crowdedness of the classes most of the teachers $(60 \%)$ use the technique of presentation and lecturing.

f) The answers of question indicate that the majority of the teachers $(90 \%)$ give their students homework, while only $10 \%$ don't do that. This means despite the large numbers of students, most of the teachers give homework.

g) The answers of question indicate that the highest percentage (40\%) of teachers give homework weekly, $30 \%$ give it daily, $10 \%$ give it monthly, and $20 \%$ give it in other times. This shows that, although there are many students in each class, teachers give students homework, because they know that it is very important for the students.

h) The answers of question eight indicate that $40 \%$ of the teachers assign $30-50 \%$ of the homework, $30 \%$ of them assign $10-20 \%$ of it, $20 \%$ of them assign $60-80$ of it and only 10 of them assign $100 \%$ of the homework. This result shows that although all the teachers give their students homework, but they are not able to mark their books because the number of students in each class. Moreover, as all of them know that it's very important to mark the books as to correct the mistakes, they cannot mark $100 \%$ of the homework. This also agrees with my hypothesis which states that large classes affect the performance of both teacher and student negatively.

i) The answers of question nine show that the percentage of the students who participate in the class, range between $10-30 \%$. This result shows that the participation of students in large classes of is weak, and this is - of course - resulted of the difficulty of following up and the help given by the teacher to each student as a result of the numbers of students in each class.

j) The answers of question ten indicate that the percentage of the students of the back - seat who participate in the class, range between $10-30 \%$ of them. This result shows that, although there is a participation from the back seat students, but this is very weak, only $10-30 \%$. In our classes, it is noticed that the weakest students used to sit at the back seats. Taska (1989, P.23) states: "it's obvious that the students at lower level where class size tends to be large, rarely have the opportunity to participate".

k) The answers of question eleven show that most of the teachers know their students names. It's well known that the first step to create friendly atmosphere inside the class, is to know the students' names. This table shows that despite the crowdedness of the classes in these schools, most of respondents know their students' names.

1) The answers of question twelve shows that the highest percentage of the teachers (40\%), know their students' names in the range between $10-30 \%$ only. Although the previous table shows that $80 \%$ of the teachers know their students' names, but, for the researcher surprise, this table indicates the remembering of these names is very weak, (only $10-30 \%$ ).

m) The answers of question thirteen show that $50 \%$ of the teacher have formal relationship with their students, 30\% have friendly relationship, and $20 \%$ have impersonal relationship. It's well observed in this result, that the majority of teachers $(50 \%)$ have formal relationship. This may be due to the fact that, teachers have to be firm inside the class, otherwise, he will not be able to control his class.

n) The answers of question fourteen indicate that there is teacher - student interaction among all the respondents and their students. This result shows that in spite of the crowdedness of the classes, there is teacher - student interaction. This result contrasted with researcher hypothesis which says that, as a result of the crowdedness of the large classes, there is a lack of teacher - student interaction.

o) The answers of question fifteen show the nature of the teacher student interaction in the class. The answers explain that the highest percentage $30 \%$ of the teachers direct questions to their students and students answer them. After that comes the discussion, then marking their exercise then finally comes the questions which are directed from the students to the teacher. Anyhow, this result explains that there is many ways of interacting with students, and there is no lack of interaction. 
p) The answers of question sixteen indicate that most of chairs and desks are arranged very close to each other. $10-20$ centimeters. It's shown from this result that there are difficulty in arranging chairs and desks in a proper way, because of the crowdedness of the class which affect the performance of the teacher inside the class as it will be shown in the answers of the following question.

\section{Conclusion}

The study analysis confirms that the hypothesis is statistically justified. It's well noticed through the questionnaire that:

a) Large classes affect both teachers and students negatively.

b) Teachers are aware of this problem.

This paper concludes with these major findings:

- Large classes are very noisy and uncomfortable for both teachers and students. So teachers keep shouting and speaking in a loud voice so as to enable students to hear them clearly. Some are indifferent to what the students are doing, because they are not able to control them.

- Students, sometimes, cannot understand anything of what teacher says or asks them to do.

- The large class environment is not suitable for teaching and learning English.

The researcher suggests that the following areas should be investigated:

- Research in teaching large classes need to be reviewed so as to find the best techniques for teaching these classes.

- Studies on teacher training and the use of educational technology are to be developed to help teachers to cope with this problem.

These points are recommended to be thought of:

- More attention must be given to solve the problem of teaching English to large classes.

- Appropriate methodology of handling large classes must be thought of as to help teachers in dealing with such a problem.

\section{REFERENCES}

[1] Betty, K. (1989). Paper on large classes. Lancaster: University of Lancaster.

[2] David J., Paul, D. and Carol D. (1981) Methods for Teaching. Charles E. Merril Publishing Company.

[3] Donn, B. ((1987) Teaching Oral English. Longman. Handbook for Language Teachers.

[4] K.U. Qian (1992) English Forum.

[5] L.A. Hill \& Michael Dobbyn (1981). A teacher Training Course for Teacher of EFL, London: Macmillan.

[6] Rob Nolasco \& Arther (1988). Large Classes. Macmillan Publisher. Ltd.

Citation: Afaf Abdelrahim, Jalaleldin Ahmed. "How to Deal with Underprivileged Classroom." International Journal of Humanities Social Sciences and Education (IJHSSE), vol 4, no. 8, 2017, pp. 58-64. doi:http://dx.doi.org/10.20431/2349-0381.0408008.

Copyright: (c) 2017 Authors. This is an open-access article distributed under the terms of the Creative Commons Attribution License, which permits unrestricted use, distribution, and reproduction in any medium, provided the original author and source are credited. 